\title{
Functional group/guild modelling of inter-specific pathogen interactions: A potential tool for predicting the consequences of co-infection
}

\author{
J. LELLO' ${ }^{1}$ and T. HUSSELL ${ }^{2}$ \\ ${ }^{1}$ School of Biosciences, Cardiff University, Biomedical Sciences Building, Museum Avenue, Cardiff, CF10 3US \\ ${ }^{2}$ Kennedy Institute, Imperial College London, ARC Building, Charing Cross Campus, 1 Aspenlea Road, London, W6 8LH
}

(Received 26 September 2007; revised 14 February 2008, 17 March 2008; first published online 14 May 2008)

\begin{abstract}
SUMMARY
Although co-infection is the norm in most human and animal populations, clinicians currently have no practical tool to assist them in choosing the best treatment strategy for such patients. Given the vast range of potential pathogens which may co-infect the host, obtaining such a practical tool may seem an intractable problem. In ecology the joint concepts of functional groups and guilds have been used to conceptually simplify complex ecosystems, in order to understand how their component parts interact and may be manipulated. Here we propose a mechanism by which to apply these concepts to pathogen co-infection systems. Further, we describe how these groups could be incorporated into a mathematical modelling framework which, after validation, could be used as a clinical tool to predict the outcome of any particular combination of pathogens co-infecting a host.
\end{abstract}

Key words: Functional groups, guilds, co-infection, mixed infection, pathogens, modelling.

\section{THE IMPORTANCE OF CO-INFECTION}

For the majority of human and animal populations worldwide, infectious disease is not the result of a single pathogen, but the consequences of multiple pathogens infecting the host simultaneously (Christensen et al. 1987). Even in cases where current infection is the result of a single pathogen species, prior history of infection may be important in determining the outcome of current infection (Walzl et al. 2000).

Despite the fact that co-infection can influence the clinical outcome of disease, there is little information in the literature, with the possible exception of concurrent infections with HIV (Harms and Feldmeier, 2002; Kontorinis, Agarwal and Dieterich, 2005; Rockstroh, 2006; Sullivan et al. 2006), as to the consequences of particular pathogen co-infection combinations. This paucity of data leaves the clinician without a clear idea of how any particular combination of infectious agents may alter the course of disease or the efficacy of any treatment regime. Even where clinicians do realise the potential problems caused by co-infection, they have little choice but to treat the various pathogen species as if each were infecting the host singly. Such decisions are

Corresponding author: Dr Joanne Lello, School of Biosciences, Cardiff University, Biomedical Sciences Building, Museum Avenue, Cardiff, CF10 3US; Tel: 02920875885 ; Fax: 02920 874562; E-Mail: lelloj@cardiff. ac.uk. inevitable given that most pathogen control strategies have been extended from laboratory studies, in which hosts are infected with only one pathogen at time. No current mechanism exists by which clinicians can make informed decisions about best practice when presented with a co-infected patient. Nevertheless, it is becoming increasingly clear, from both theoretical and clinical studies, that treating coinfected patients as if they were infected with a series of isolated pathogen species is insufficient and may lead to ineffective disease control or even to increased damage to the host (Lello et al. 2004; Brown et al. 2005).

Co-infection has consequences for both the host and the pathogen species involved. For example, concurrent or prior infection may increase pathogen virulence and this in turn could lead to increased disease severity (Graham et al. 2005; Abu-Raddad, Patnaik and Kublin, 2006; Deka et al. 2006; Hughes and Shafran, 2006; Page, Scott and Manabe, 2006). Recent studies have highlighted how the severity of the disease caused by one organism may be altered by the presence of a second species. For example, infection with Hepatitis $\mathrm{C}$ has been reported to increase the incidence of AIDS defining events in HIV infected patients (Stebbing et al. 2005). Similarly, chickens co-infected with cryptosporidium and Marek's Disease show increased severity of both diseases when compared to singly infected individuals (Abbassi et al. 2000). However, it should be noted that not all co-infection leads to increased severity of disease. Indeed, in some cases 
co-infection may lead to decreased disease severity. For example, one study shows that infection with rotavirus is less severe if the host is concurrently infected with Giardia lamblia (Bilenko et al. 2004). Similarly, influenza-induced pathology in mice is ameliorated by co-infection with Trichinella spiralis (Furze, Hussell and Selkirk, 2006). In these latter two cases, it may be advisable to hold back on treatment of one species (in these cases G. lamblia and T. spiralis) until after the more damaging infection has been cleared, rather than attempting to treat both diseases simultaneously. Without a clear understanding of the dynamics of the whole system, such delayed treatment might have other unforeseen consequences.

The duration of the disease may also be altered by co-infection (Walzl et al. 2000) and extended infections may be due to increased survival or fecundity of the parasite or to a reduced capacity of the host to resist or eliminate the infection(s). Whatever the cause, increased disease duration can mean a longer period of infectiousness for the patient (and hence transmission opportunities for the pathogens) and may also lead to increased disease severity, simply because the host accumulates damage over a longer period.

Finally, both treatment efficacy and the degree to which the treatment itself harms the patient may be affected by co-infection. For example, a recent study has shown that treatment for schistosomiasis causes an increase in HIV viral load in co-infected individuals (Brown et al. 2005). Further, co-infection may buffer pathogen species from the effects of a treatment strategy, or could favour one pathogen over another (thus producing an apparent competition and potentially changing the aetiology of the disease). Where competition between pathogen species has resulted in a more virulent species being suppressed, targeted control of the competitor could release the virulent species from its constraints and the host may suffer a more severe disease than if the treatment had not occurred (Lello et al. 2004).

There is undoubtedly a growing comprehension of the importance of co-infection, which may be seen in the rapid increase in the percentage of publications in which the words, co-infection or mixed infection are found within the title (Fig. 1). Currently, only prior knowledge of the consequences of particular combinations of pathogens can provide the clinician with any solid decision-making tool and there are very few published examples of such co-infection data. Why then has no mechanism been developed to aid clinicians in dealing with co-infected patients? We believe that the reason is that the problem is viewed as intractable, given the virtually infinite number of possible combinations of pathogens with which human and animal hosts may be infected. In order to provide clinicians with a tool with which they could deal with any potential co-infection combination,

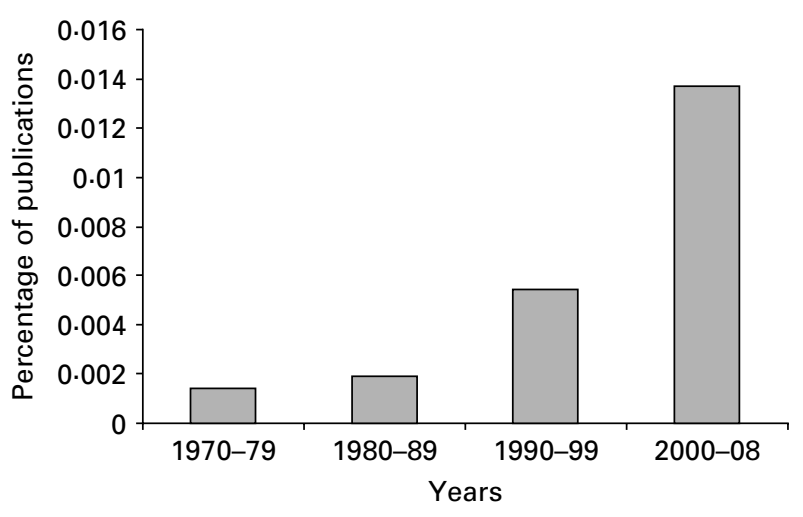

Fig. 1. Increase in the percentage of publications containing the terms 'co-infection' or 'mixed infection'

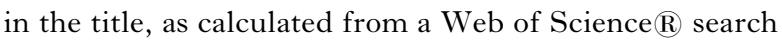
between 1970 and 2008 .

some simplification mechanism must be found. In this review we present one possible mechanism for simplification. It is important to be clear that we are not proposing this mechanism as the only potential simplification that could be undertaken, nor will we present a finished product, but rather we describe one possible method for achieving this aim.

\section{PATHOGEN INTERACTION THROUGH IMMUNITY}

Every pathogen will have some degree of effect on the immune system of the host, stimulating or suppressing particular pathways of the immune response. These various pathways are interlinked through upand down-regulatory mechanisms. Therefore, unless the immune response against a pathogen is entirely localised and the pathogens involved in the coinfection are spatially separated, we should expect that one organism would usually have an effect upon another when co-infecting a host. For example, in humans, there is a known see-saw response between the $T h_{1}$ and $T h_{2}$ branches of the immune response, such that an increase in the $T h_{1}$ response generally results in a lower $\mathrm{Th}_{2}$ response and vice versa (Diehl and Rincon, 2002). Page et al. (2006) discuss the effects of a strongly $\mathrm{Th}_{2}$-inducing infection with the mouse nematode, Heligmosomoides polygyrus, on the host response to a subsequent infection with the bacterium Helicobacter felis. The helminth infection is associated with a down-regulation of the $\mathrm{Th}_{1}$ response against the bacterium. In this case the pathology of the disease is largely immune mediated and hence this down-regulation could be interpreted as a positive outcome. Conversely if a $\mathrm{Th}_{1}$-inducing organism such as $T$. gondii infects the host first, then the $T h_{1}$-induced damage increases.

It should be noted that direct interactions between pathogen species are also possible, but even less documentation may be found on the consequences of these co-infections. Further, it is generally more difficult to establish the mechanism for direct 
pathogen interactions, as the tools with which they could be elucidated have not been developed to the same extent as immunological parameter assessments. Co-infecting pathogens are often separated into different physical niches within the host, either in different tissues and organs or in different cellular compartments (e.g. outside of host cells, free within the cytoplasm or in vesicles within the cytoplasm) and direct interactions are less likely to occur in such cases. Therefore, we believe that direct interactions are likely to make up a smaller subset of the overall potential co-infection mechanisms, although this is open for debate. Whatever the overall importance of such non-immune-mediated interactions, because of the lack of available data on this topic we will not consider them further. Nevertheless, in the limited number of pathogen systems where such information is available, there is no reason that they could not be included in the overall framework described hereafter.

FUNCTIONAL/GUILD GROUPINGS: A MECHANISM FOR SIMPLIFICATION

Well-established concepts in ecology are the functional group and the guild (Catovsky, 1998; Blondel, 2003; Davic, 2003; Biber, Harwell and Cropper, 2004; Davis et al. 2004; Dumay et al. 2004; Wardle and Zackrisson, 2005; Petchey and Gaston, 2006; Storkey, 2006; Pedersen and Fenton, 2007). The two terms are often used synonymously and may indeed define the same groups under certain circumstances. However, in a review of the topic by Blondel (2003) the two terms are considered as separate, with the functional groups being associated with 'effects' upon the ecosystem (functions they perform) and guilds being defined by resource use or 'response' to the ecosystem. Of course, any particular organism may be categorised either into a functional group or a guild, and it would be possible to create a new group definition which combines both functional group and guild concepts. Functional groups and guilds may contain taxonomically related species but can also cross such taxonomic boundaries (Blondel, 2003; Hood et al. 2006). For example, the broad functional group 'decomposers' may include bacteria, fungi and soil animals such as earthworms and collembolans (Milcu et al. 2006). Similarly, the oceanic functional group termed calcifiers includes phytoplankton, zooplankton and reef-building coral species (Hood et al. 2006). There has been wide debate about the definition and usefulness of functional groups and guilds, and it is possible for the same organism to be placed into entirely different groupings (under either term) based upon the criteria used to define the groups (Petchey and Gaston, 2006). Obviously, the usefulness of this group approach to conceptually simplifying complex ecosystems is only as good as the accuracy of the group definitions. The best examples of using such groupings effectively are those where the groups are defined in association with the question being investigated. For example, if the question relates to nutrient cycling, then the definition of the functional groups must be directly related to an organism's place in this process (Hood et al. 2006; Petchey and Gaston, 2006). Any particular organism might have a different grouping if the question being examined was related to some other aspect of its environmental activity or response, e.g. trophic level. Similarly, organisms may shift between groups at different stages of their life cycle (Blondel, 2003) and the groupings should be seen as dynamic. If the groups are clearly defined then the relationships between them are also clear and predictable e.g. primary producers fix energy from the sun, or other sources, and provide food for the first trophic level of consumers.

One advantage to creating functional groups is that any novel organism's influence upon its ecosystem may be predicted by assigning that organism to one of the defined functional groups, based on some typical group characteristics (King, Andersen and Cutter, 1998; Storkey, 2006). Plant ecologists have made particularly good use of this concept in a number of studies, where plant functional groups are defined based upon combinations of easily measured characteristics such as leaf thickness or tree height (Foster and Brooks, 2005; Poorter, Bongers and Bongers, 2006).

Ecosystem models, using functional groups, have proven highly effective as methods to understand the mechanics of ecosystems and to predict the outcomes of perturbations to those systems (Biber et al. 2004; Dumay et al. 2004; Storkey, 2006). Fulton et al. (2004) describe the simplification of a very complex Integrated Bay Ecosystem Model (IGBEM) by use of functional groups. The resulting Bay Model 2 (BM2) agreed well with the more complex model in its capacity to predict a range of features from predicted biomass through to community composition of the benthos, and, in fact, was a better predictor of this latter feature. As the functional groups alone are clearly accurate predictors of the system, this guides understanding of what the key processes are within that system. Biber et al. (2004) describe the use of a functional group model of macro-algae within a seagrass habitat in South Florida which they use to predict annual biomass dynamics. They validated the model with real data and then used it to examine the productivity responses under a range of stress conditions imposed by freshwater discharges. Although the model failed to predict responses in canal-influenced conditions, it did very well under sheet-flow and oceanic conditions, and the failure in the former case was thought to be due to a lack of data on one of the functional groups. These examples provide evidence of the potential usefulness of functional group models and show that, where they 
fail, they are also useful in defining what additional information is required to improve their accuracy.

APPLYING THE FUNCTIONAL GROUPAPPROACH TO PATHOGENS

For a pathogen infecting a host, its ecosystem consists of the components of the host biology and immunology and of any other species of pathogen with which the first pathogen species may interact. Importantly, any of these components of the ecosystem may be altered by the actions of the other components. If we take a functional group guild approach, with organisms defined by their effects upon and responses to the ecosystem, then the usual mechanism for grouping pathogens by taxa (e.g. viruses, protozoa, bacteria, helminths) may not apply. We might find that one functional group contains a number of intracellular viruses, bacteria and protozoa, all of which invade host cells and evade the immune response for a time (Werling et al. 1998; Carlyon and Fikrig, 2003; Shumilla et al. 2004). Conversely, two helminth species might be placed in different functional categories because their effects on immune components are markedly different (Turner et al. 2003; Stadecker et al. 2004). However, it is worth noting that functional groups and guilds do often contain multiple organisms from the same taxonomic grouping (Blondel, 2003).

There is little discussion in the literature regarding the use of simplifying approaches to understanding pathogen, in-host, ecosystems. Recently, Pedersen and Fenton (2007) described a possible framework by which pathogens might be assigned to guilds. They suggest that guilds be defined by shared niche, which they further define by using three axes, the resource axis (food), the location axis (infection site(s)) and the immunological axis (i.e. which immune components are stimulated). In adding the third, immunological, axis the authors cross from a resource use grouping (Blondel's (2003) description of a guild) and into a grouping concerned with the functional role the pathogen plays in the ecosystem (Blondel's functional group). This approach is more holistic and, as suggested earlier, a new categorisation term which includes both the functional group and guild concept might be needed here. In the absence of such a new grouping term, and for simplicity, we will refer hereafter to the term functional group and drop the term guild.

An additional consideration in using an immunological axis for defining pathogen groupings is that it could be argued that stimulation of the immune response is not a true function of the pathogen but rather a function of the environment (the host) acting against the pathogen. As such, some may argue that immune stimulation should not be used to define the pathogens themselves. However, as many pathogens are known to manipulate the host immune system to their advantage and as the specific immune response of the host would not exist without the presence of the pathogen, the two are so inextricably linked that we agree with Pedersen and Fenton (2007) and believe that the host immune response may legitimately be used as a grouping factor.

The response of the host to the presence of particular pathogens could be considered in terms of Immunological Activity Groups (IAG). A Pathogen Functional Group (PFG) which is defined on the basis of IAG, would have two components. If a pathogen stimulates an inappropriate host immune response (i.e. a response which does not lead to disease control and/or clearance) then it may have a different IAG for ongoing disease compared to a controlled infection.

Application of a pathogen functional group concept could be an extremely useful tool in exploring the relationships between pathogens in concomitant infections, provided that a suitable IAG can be created. These IAGs are formed in same manner as functional groups and as such must be chosen with a clear question in mind. In this case, we wish to establish how the pathogens may interact through the host immune system. Therefore, our definitions of the groups should be driven by the potential forms of immune stimulation that pathogens invoke and the forms of immune response that the pathogens are subsequently controlled by.

Much is known about the position of individual immune components (at least those that are commonly recorded) in the various pathways of the immune response and, in turn, the inter-relationships of these pathways are also well understood. Therefore, if functional groups are defined on the basis of the IAG, then prediction of the relationships between these groups should also be possible. Defining pathogen functional groups should allow assessment of both the likelihood of specific pathogen interactions and the mechanisms by which those interactions may be mediated. Furthermore, models constructed using these groupings would allow the dynamics of the pathogen infections and the consequences of perturbations (e.g. treatment strategies) to those dynamics to be predicted.

At the finest scale, the intricacies of how pathogens interact with the host immune system are probably as diverse as the species themselves. However, at a median level of complexity many parasite species will share similar interaction mechanisms and it is at this level that functional groupings could be useful. The key to categorizing the functional groups is in defining the level of complexity at which the groupings need to be set.

CREATING THE PFG MODEL

We propose that there should be five key stages to the production of a clinically useful functional group 
model. First, a database should be constructed using the current immunological literature on laboratoryconducted, single-species infection experiments. The database should contain the recorded immune parameters for specific pathogen infections and, where known, whether or not these immune responses were associated with successful pathogen control (leading to cessation of infection) or with an on-going infection (acute or chronic). Secondly, this database would be used to form the IAG. Thirdly, the Pathogen Functional Groups (PFG) would be created. A PFG would be defined by two IAG scores, one for the pathogen's stimulatory effects on the immune system and one for the IAG by which the pathogen is successfully controlled. The fourth step in the process would be the model construction, with the links between groups based upon the known relationships between the IAG. The final step is validation and requires the model to be tested against real co-infection data.

Suitable data do exist, at least for humans and domestic animals, which would allow the construction of a database for the formation of the IAG. However, such a process is a very large undertaking and is beyond the scope of this review. Nevertheless, here we demonstrate the potential to undertake this process. We construct a small preliminary database using a limited number of data fields and organisms and use it to construct an example of an IAG. From our example IAG we then form preliminary pathogen functional groups (PFG). The number of PFG is simply the number of unique combinations of the two IAG scores. Although this will potentially lead to quite high numbers of PFG, the modelling of these groups remains comparatively simple as the IAG will always be fewer in number and it is the IAG relationships that ultimately describe the model.

It is important to stress that the database described hereafter is not to be considered as anything more than an example of how such a database may be formed and the uses to which it can be put. Further, the functional groups and example model produced from those groups are also given solely as examples of the proposed process and are not in any way intended to be definitive, nor are we proposing that the model described in this paper would be useful for clinical purposes as it stands. What we hope to achieve is to provide a framework by which researchers may continue to explore this topic.

\section{Step 1: Database production}

To produce an example pathogen/immunological database we preliminarily searched for the terms, 'interleukin, T-helper, Th1, Th2 and Th0' in the

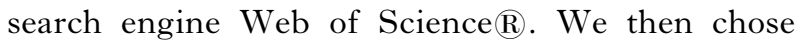
fourteen of the infectious organisms (from the first few pages of the search) which yielded frequent hits in this first search (2 fungal, 3 helminth, 3 protozoan, 3 bacterial and 3 viral pathogens). Next, we conducted a more detailed search on these organisms using the species or genus name (as appropriate) and a partial list of cytokines (i.e. IL-1, IL-2, IL-4, IL-5, IL-6, IL-10, IL-12, IL-13, IFN- $\gamma$ and TNF- $\alpha$ ). Cytokine profiles were scored as having either no or no recorded response $(0)$, a down-regulation of that response $(-1)$, or an up-regulation of the response $(+1)$. Using only the cytokines described above obviously constrained the database and we emphasise that this was purely a constraint for the purposes of this example. We also recorded the pathogen taxon as either fungal, viral, bacterial, protozoan or helminth.

For a full database we would recommend that there be no a priori restrictions on which immune features were recorded. All aspects of immune response, including the cytokine profiles, information on TLR stimulation (Liew et al. 2005), cellular immune responses and genetic data could potentially be useful. An extended database could also include pathogen traits, such as infection site, the intra/ extracellular nature of the organism, its taxonomic group, trophic level, virulence and relative growth rates. Additionally, traits of the host could be included where they may influence the immunological outcome, e.g. species, host age and genetic information such as mouse strain. If a damage component is to be included in the model it would also be useful to incorporate information as to the nature of the pathogenesis of the disease, i.e. whether it is directly pathogen mediated or caused via the actions of the immune response. If these additional data are associated with particular immune activity groupings with sufficient specificity, then these pathogen and host traits could be used to assign novel organisms to their specific IAG (and then their subsequent PFG) without the need for direct measurement of the indicator immune traits themselves.

Within our example database we divided the immunological profiles into those which were associated with ongoing disease and those which were associated with disease control or cessation. Multiple studies from different authors (Table 5) were used to make up the profiles for each disease and where studies disagreed the majority finding was taken. For a full database we would suggest that where a disagreement is found in the literature both sets of information are recorded as separate entries in the database and a weighting column added, based on the number of papers describing each type of immune response. Again we should make clear that we did not conduct an exhaustive literature search for each organism in this example.

Due to the limited number of records and information in our database we conducted a further simplification with a grade given (on the basis of the cytokine profile) to indicate whether the disease was 
Table 1. Pathogen database example showing pathogen species or genus, taxa $(B=$ bacteria, $F=$ fungi, $\mathrm{H}=$ helminth, $\mathrm{P}=$ protozoa, $\mathrm{V}=$ virus) of the pathogen, whether the immune profile is representative of ongoing disease ( $\mathrm{D}$ - upper section) or of an infection which is being controlled (C - lower section), the proposed functional group membership (see also Table 2) and the score for $\mathrm{T}$ cell responses (no or no recorded response $=0$, up-regulated response $=1$, down-regulated response $=-1$ ) of each pathogen

\begin{tabular}{|c|c|c|c|c|c|c|c|}
\hline Organsims & Taxa & $\begin{array}{l}\text { Disease/Control } \\
\text { Profile }\end{array}$ & $\begin{array}{l}\text { Functional } \\
\text { Group }\end{array}$ & $\mathrm{Th}_{1}$ & $\mathrm{Th}_{2}$ & $\mathrm{Th}_{17}$ & $\mathrm{~T}_{\text {reg }}$ \\
\hline Aspergillus spp. & $\mathrm{F}$ & $\mathrm{D}$ & 1 & 0 & 1 & 0 & 1 \\
\hline Ascaris suum & $\mathrm{H}$ & $\mathrm{D}$ & 1 & 0 & 1 & 0 & 1 \\
\hline Schistosoma spp. & $\mathrm{H}$ & $\mathrm{D}$ & 1 & 0 & 1 & 0 & 1 \\
\hline Trichinella spiralis & $\mathrm{H}$ & $\mathrm{D}$ & 1 & 0 & 1 & 0 & 1 \\
\hline Leishmania spp. & $\mathrm{P}$ & $\mathrm{D}$ & 1 & 0 & 1 & 0 & 1 \\
\hline Candida spp. & $\mathrm{F}$ & $\mathrm{D}$ & 2 & 1 & 1 & 1 & 0 \\
\hline Giardia spp. & $\mathrm{P}$ & $\mathrm{D}$ & 2 & 1 & 0 & 1 & 0 \\
\hline Malaria & $\mathrm{P}$ & $\mathrm{D}$ & 2 & 1 & 0 & 0 & 0 \\
\hline Measles & $\mathrm{V}$ & $\mathrm{D}$ & 2 & 1 & 1 & 1 & 0 \\
\hline Listeria spp. & B & $\mathrm{D}$ & 3 & 1 & 0 & 1 & 1 \\
\hline Mycobacterium tuberculosis & B & $\mathrm{D}$ & 3 & 1 & 0 & 1 & 1 \\
\hline Neisseria spp. & B & $\mathrm{D}$ & 3 & 1 & 0 & 1 & 1 \\
\hline Trichuris spp. & $\mathrm{H}$ & $\mathrm{D}$ & 3 & 1 & -1 & 0 & 1 \\
\hline Rotavirus & $\mathrm{V}$ & $\mathrm{D}$ & 3 & 1 & -1 & 1 & 1 \\
\hline RSV & $\mathrm{V}$ & $\mathrm{D}$ & 4 & -1 & 1 & 0 & 1 \\
\hline Trichinella spiralis & $\mathrm{H}$ & $\mathrm{C}$ & 1 & 0 & 1 & 0 & 1 \\
\hline Aspergillus spp. & $\mathrm{F}$ & $\mathrm{C}$ & 2 & 1 & 0 & 1 & 0 \\
\hline Giardia spp. & $\mathrm{P}$ & $\mathrm{C}$ & 2 & 1 & 0 & 0 & 0 \\
\hline Measles & $\mathrm{V}$ & $\mathrm{C}$ & 2 & 1 & 1 & 1 & 0 \\
\hline RSV & $\mathrm{V}$ & $\mathrm{C}$ & 2 & 1 & 0 & 0 & 0 \\
\hline Candida spp. & $\mathrm{F}$ & $\mathrm{C}$ & 3 & 1 & 0 & 0 & 1 \\
\hline Malaria & $\mathrm{P}$ & $\mathrm{C}$ & 3 & 1 & -1 & 1 & 1 \\
\hline Neisseria spp. & $\mathrm{B}$ & $\mathrm{C}$ & 3 & 1 & 0 & 1 & 1 \\
\hline Schistosoma spp. & $\mathrm{H}$ & $\mathrm{C}$ & 3 & 1 & 1 & 0 & 1 \\
\hline Rotavirus & $\mathrm{V}$ & $\mathrm{C}$ & 3 & 1 & -1 & 0 & 1 \\
\hline Ascaris suum & $\mathrm{H}$ & $\mathrm{C}$ & 4 & -1 & 1 & 0 & 0 \\
\hline Trichuris spp. & $\mathrm{H}$ & $\mathrm{C}$ & 4 & -1 & 1 & 0 & 0 \\
\hline Leishmania spp. & $\mathrm{P}$ & $\mathrm{C}$ & 5 & 1 & 1 & 0 & -1 \\
\hline Listeria spp. & $\mathrm{B}$ & $\mathrm{C}$ & 5 & -1 & 0 & 0 & -1 \\
\hline Mycobacterium tuberculosis & $\mathrm{B}$ & $\mathrm{C}$ & 5 & 1 & 1 & 1 & -1 \\
\hline
\end{tabular}

Table 2. Defining features of the proposed immunological activity groups, using the $\mathrm{T}$ cell profiles. Blank cells indicate that any response is allowable. No response $=0$, an up-regulated response $=1$ and a down-regulated response $=-1$

\begin{tabular}{lcccc}
\hline \hline $\begin{array}{l}\text { Functional } \\
\text { group }\end{array}$ & $\mathrm{Th}_{\mathbf{1}}$ & $\mathrm{Th}_{\mathbf{2}}$ & $\mathrm{Th}_{17}$ & $\mathrm{~T}_{\text {reg }}$ \\
\hline 1 & 0 & 1 & & 1 \\
2 & 1 & & & 0 \\
3 & 1 & & & 1 \\
4 & -1 & 1 & 0 & -1 \\
5 & & & & \\
\hline \hline
\end{tabular}

associated with up, down or no regulation of the $\mathrm{Th}_{1}$, $\mathrm{Th}_{2}, \mathrm{Th}_{17}$ and $\mathrm{T}$ regulatory cell responses (Table 1 ).

\section{Step 2: Defining the IAG}

Once a database has been produced it may be used to define the immune activity groups. Our groupings were defined simply by establishing how many unique profiles could be found in the dataset. In this case we find five distinct profiles which are characterized in Table 2. Fig. 2 diagrammatically represents the proposed relationships between our defined immune activity groups.

\section{Step 3: Defining the PFG}

Once the immune activity groups have been established the pathogen functional groups can also be created. This step is a simple process, with each pathogen being given two IAG scores as described above. For our pathogens 12 distinct PFG were defined (Table 3). This may appear to be a large number of groups to deal with but, as stated earlier, each group is still centred on only the five immune activity groups and their influences upon one another are relatively simple to define and model. Of further interest is the grouping of unrelated taxa in some of these PFG. Measles and Giardia spp. both show profiles in PFG 6, characterized by a $\mathrm{Th}_{1}$ response with no T-regulatory involvement. Rotavirus and Neisseria spp. have profiles in PFG 9, characterized 


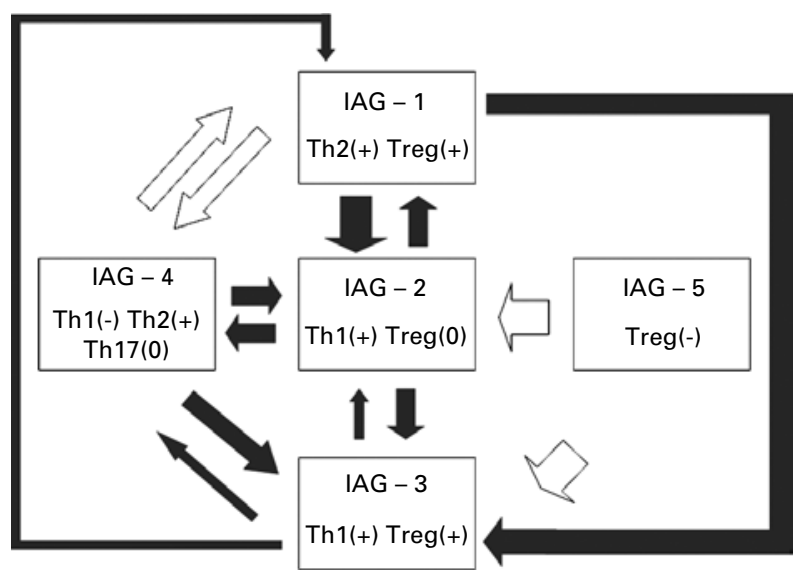

Fig. 2. Hypothesised relationship between the immune activity groups (IAG). Black arrows indicate down-regulatory processes and white arrows indicate up-regulatory processes. The thickness of the arrow equates to the proposed strength of the action of one group upon another. $T$ regulatory mechanisms are assumed to have down-stimulatory effects on $\mathrm{Th}_{1}$ responses only.

by a $\mathrm{Th}_{1}$ response but moderated by a $\mathrm{T}$ regulatory cell response. Listeria spp. and Mycobacterium tuberculosis show profiles in PFG 11, which for their disease profile show the same immune profile as PFG 9 but for their control response are characterized by a down-regulation of the $\mathrm{T}$ regulatory cell response.

\section{Why do some PFG contain only one IAG?}

In our defined PFG, the IAG for the disease profile is sometimes the same as for the control profile. There are three possible explanations for this. Firstly, organisms which show acute dynamics may stimulate an immune response that is effective at clearing the disease and their chief strategy for survival is to reproduce and transmit rapidly before the immune system has time to mount the effective response. Secondly, the pathogen may show acute but recurrent dynamics, wherein the immune response stimulated is effective against a certain lifestage of the pathogen, but the pathogen also has a life-stage within the host which is resistant, dormant or can sequester away from the immune components. Similarly, where there is no or only short immune memory, re-infection with the same species, can also result in these acute dynamics. The latter two possibilities are not taken into account in our simple examples, but could be incorporated in the full database, for development of the IAG and PFG and the subsequent model.

\section{Step 4: Production of the functional group model}

As we have shown, functional group models have proven useful in determining likely changes in an ecosystem given perturbations to that system and
Table 3. Pathogen functional group (PFG) allocation, revealing 12 distinct functional groups defined by their ongoing disease (Disease) and infection control (Control) immune activity group (IAG) profiles

\begin{tabular}{llllc}
\hline \hline Organism & Taxa & Disease & Control & PFG \\
\hline Trichinella spiralis & $\mathrm{H}$ & 1 & 1 & 1 \\
Aspergillus spp. & $\mathrm{F}$ & 1 & 2 & 2 \\
Schistosoma spp. & $\mathrm{H}$ & 1 & 3 & 3 \\
Ascaris suum & $\mathrm{H}$ & 1 & 4 & 4 \\
Leishmania spp. & $\mathrm{P}$ & 1 & 5 & 5 \\
Measles & $\mathrm{V}$ & 2 & 2 & 6 \\
Giardia spp. & $\mathrm{P}$ & 2 & 2 & 6 \\
Malaria & $\mathrm{P}$ & 2 & 3 & 7 \\
Candida spp. & $\mathrm{F}$ & 3 & 2 & 8 \\
Rotavirus & $\mathrm{V}$ & 3 & 3 & 9 \\
Neisseria spp. & $\mathrm{B}$ & 3 & 3 & 9 \\
Trichuris spp. & $\mathrm{H}$ & 3 & 4 & 10 \\
Listeria spp. & $\mathrm{B}$ & 3 & 5 & 11 \\
Mycobacterium & $\mathrm{B}$ & 3 & 5 & 11 \\
tuberculosis & & & & \\
RSV & $\mathrm{V}$ & 4 & 2 & 12 \\
\hline
\end{tabular}

model manipulations can be used to assess the best solutions to ecosystem problems. Models are also useful because multiple model manipulations can be carried out without the need for expensive and sometimes impractical experimentation. Creation of a functional group model for pathogen ecosystems would allow similar system engineering to be undertaken and thus introduce a mechanism for more efficacious pathogen control and prediction of coinfection consequences.

The model should contain the descriptors of the PFG influences on the immune components (in our example the $\mathrm{T}$ cells) and also the effects of those immune components upon the pathogen. To assess the effects of the immune components on the pathogens we need to know whether the pathogen is in the disease or clearance phase, in other words is the immune response appropriate for controlling the pathogen. As stated earlier, pathogens may move between functional groups depending on stage of infection. For simplicity in this example we choose two pathogens for which their two IAG are the same and for which there is published evidence of the consequence of co-infection. We therefore consider the example of a co-infection with the protozoan Giardia lamblia and the helminth Trichinella spiralis. (von Allmen et al. 2006), which the literature suggests should lead to an increase in the number of G. lamblia trophozoites if the infections are concurrent.

According to our example PFG classification, Trichinella spp. fall into PFG 1, with both IAG scoring 1 . This IAG is chiefly characterized by the up-regulation of both $\mathrm{Th}_{2}$ and $\mathrm{T}$ regulatory cell responses. Giardia spp. are classified as PFG 6 in our 
Table 4. Parameter values for the model describing the interaction between pathogen functional groups 1 and 3

\begin{tabular}{ll}
\hline \hline Parameter & Value \\
\hline $\mathrm{a}_{1}$ & 0.9 \\
$\mathrm{a}_{2}$ & 2.8 \\
$\mathrm{~b}_{1}$ & 0.35 \\
$\mathrm{~b}_{2}$ & 1.2 \\
$\mathrm{c}_{1}$ & $1.5 \mathrm{E}-5$ \\
$\mathrm{c}_{2}$ & $1.0 \mathrm{E}-3$ \\
$\mathrm{c}_{\mathrm{r}}$ & $1.0 \mathrm{E}-3$ \\
$-\gamma_{1}$ & 0.1 \\
$-\gamma_{2}$ & 0.1 \\
$-\gamma_{\mathrm{r}}$ & 1.0 \\
\hline \hline
\end{tabular}

proposed system, with both IAG scoring 2 . Immune activity group 2 is characterized by an up-regulation of the $\mathrm{Th}_{1}$ response and no evidence of any $\mathrm{T}$ regulatory activity.

A functional group simulation model was formed in the statistical package, Mathematica (v6.0). The model consisted of a series of differential equations for describing the functional groups and their interactions with the components of the immune response. The functional group equations are defined below:

$d F_{1} / d t=a_{1} \cdot F_{1}-b_{1} \cdot F_{1} \cdot e^{T h 2}$

$d F_{3} / d t=a_{2} \cdot F_{3}-b_{2} \cdot F_{3} \cdot e^{T h_{1}}$

where $F_{i}$ refers to the functional group number $i$; $a_{i}$ is the relative growth rate of the pathogen population in functional group $i ; b_{i}$ is the relative death rate of the pathogen population in functional group i. Further there are three immune parameters modelled, the $\mathrm{Th}_{1}$ response, the $\mathrm{Th}_{2}$ response and the $\mathrm{T}$ regulatory cell response $\left(\mathrm{T}_{\mathrm{r}}\right)$. We assume that over the time span of the model no immune decay occurs. $\mathrm{The} \mathrm{Th}_{1}$ and $\mathrm{Th}_{2}$ responses are assumed to have equivalent downregulatory effects upon one another. Additionally, the $T_{r}$ response has a down-regulatory effect on the $\mathrm{Th}_{1}$ production which is ten-fold the level of the direct effects of $T h_{1}$ and $T h_{2}$ upon one another. The formulae for these immune responses are below:

$d T h_{1} / d t=c_{1} \cdot F_{3} \cdot e^{-\gamma_{r} \cdot T_{r}-\gamma_{2} \cdot T h_{2}}$

$d T h_{2} / d t=c_{2} \cdot F_{1} \cdot e^{-\gamma_{1} \cdot T h_{1}}$

$d T_{r} / d t=c_{r} \cdot F_{1}$

Where $c_{i}$ is the stimulation rate of the immune response for immune response $i ;-\gamma_{j}$ is the moderator of the down-regulatory effect of the immune response j upon immune component $i$. a)

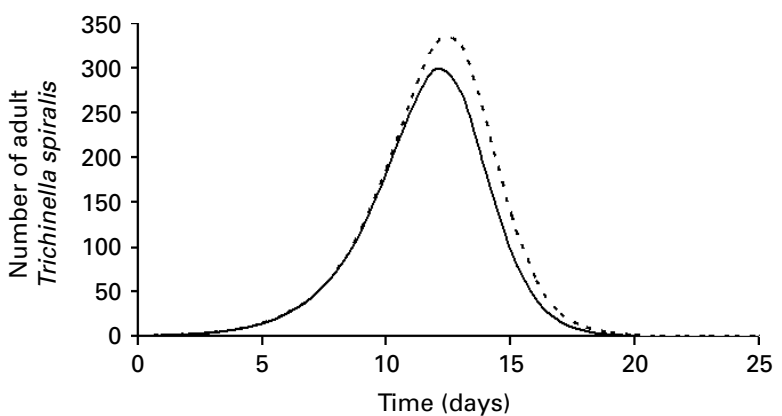

b)

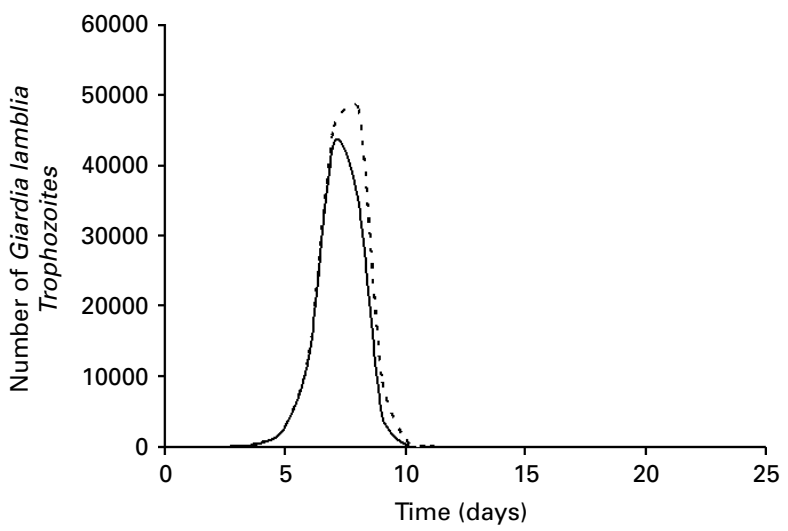

Fig. 3. Example pathogen functional group (PFG) model simulations for the single and mixed infections of functional group 1 (Trichinella spiralis.) and functional group 6 (Giardia lamblia.). Panels (a) and (b) show the model dynamics for the infections with PFG 1 and PFG 6 respectively. Solid lines represent single species infections and dashed lines represent the pathogen dynamics in co-infection.

Detailed descriptions of pathogen growth and death rates are often absent from the literature. There is usually sufficient data to describe the organisms qualitatively. For example, we can establish from the literature that Trichinella spp. infections in mice have a comparatively lower growth rate (within the host) than Giardia spp. and that T. spiralis has approximately similar temporal dynamics (14-20 day infection) to the faster replicating $G$. lamblia, (Gbakima, 1993; Gurish et al. 2004). A complete list of the parameters used for the model is given in Table 4. Parameter values were chosen to give model outputs which, in the modelled single species infections, broadly represented the pathogen dynamics described in the literature (Gbakima, 1993; Gurish et al. 2004; von Allmen et al. 2006). The growth rate of the $T$. spiralis infection (reproduction-death) was adjusted to give the approximately 350 adult worms at day 10 which was the peak of adult worm numbers in the study of Gurish et al. (2004). The outputs of the single and two species models may be seen in Fig. 3. The model successfully predicts an increase in G. lamblia trophozoites in the presence of T. spiralis. 
Table 5. List of studies used to define the immunological (cytokine) responses for each organism in the example database

\begin{tabular}{|c|c|}
\hline Organism & Studies \\
\hline Trichinella spiralis & $\begin{array}{l}\text { (Rousseau et al. 1997; Onah and Wakelin, 1999; Vallance et al. 2000; Khan et al. } \\
\text { 2001; Helmby and Grencis, 2002) }\end{array}$ \\
\hline Aspergillus spp. & (Allard et al. 2006; Stevens, 2006) \\
\hline Measles & (Karosi et al. 2006; Mikhailova et al. 2006; Tishon et al. 2006; Yanagi et al. 2006) \\
\hline Giardia spp. & (Singer and Nash, 2000; Bayraktar et al. 2005; Li et al. 2006) \\
\hline RSV & (Becker, 2006; Riffault et al. 2006; Stewart et al. 2006; Wang et al. 2006) \\
\hline Schistosoma spp. & $\begin{array}{l}\text { (Baumgart et al. 2006; Cardoso et al. 2006; Coutinho et al. 2006; Dunne et al. 2006; } \\
\text { Ferrari et al. 2006; Perona-Wright et al. 2006; Reimert et al. 2006; Sousa-Pereira et al. } \\
\text { 2006) }\end{array}$ \\
\hline Malaria & $\begin{array}{l}\text { (Dekossodo and Grau, 1993; Seoh et al. 2003; Deshpande and Shastry, 2004; } \\
\text { Ramharter et al. 2004; Farouk et al. 2005; Furuta et al. 2006; John et al. 2006; Parekh } \\
\text { et al. 2006; Seixas and Ostler, 2005; Sharma et al. 2006) }\end{array}$ \\
\hline Candida spp. & (De Bernardis et al. 2006; Egusa et al. 2006; Kosonen et al. 2006) \\
\hline Rotavirus & (Jiang et al. 2003; Azevedo et al. 2006; VanCott et al. 2006; Xu et al. 2006) \\
\hline Neisseria spp. & (Fowler et al. 2006; Morales et al. 2006; Zarantonelli et al. 2006) \\
\hline Ascaris suum & $\begin{array}{l}\text { (Deehan et al. 2002; Paterson et al. 2002; Souza et al. 2004; Dawson et al. 2005; } \\
\text { McConchie et al. 2006) }\end{array}$ \\
\hline Trichuris spp. & $\begin{array}{l}\text { (Taylor et al. 2000; Liu et al. } 2005 \text {; Parthasarathy and Mansfield, } 2005 \text {; } \\
\text { deSchoolmeester } \text { et al. 2006; Kringel et al. 2006) }\end{array}$ \\
\hline Leishmania spp. & $\begin{array}{l}\text { (Roberts, 2005; Abolhassani and Darabi, 2006; Mukherjee } \text { et al. 2006; Mullen } \text { et al. } 2006 \text {; } \\
\text { Pepe et al. 2006; Santiago et al. 2006) }\end{array}$ \\
\hline Listeria spp. & $\begin{array}{l}\text { (Torres et al. 2005; D’Orazio et al. 2006; Foulds et al. 2006; Ozoren et al. 2006; } \\
\text { Popov et al. 2006) }\end{array}$ \\
\hline Mycobacterium tuberculosis & $\begin{array}{l}\text { (Cooper et al. 1993; Feng et al. 2006; Loeuillet et al. 2006; Thom et al. 2006; } \\
\text { Warrender } \text { et al. 2006; Wieland et al. 2006) }\end{array}$ \\
\hline
\end{tabular}

It also suggests that the duration of infection (calculated as days that the pathogen count is above one) will increase. T. spiralis infection level is also predicted to increase, although no increased duration of infection is observed. However, the model only succeeds qualitatively. In the experimental system both the number of trophozoites and the duration of the infection are much more severely increased. Nevertheless, even a qualitative statement about the effects of co-infection could be useful in a clinical setting. We re-emphasise that this model is extremely simplistic and is only a demonstration of how such techniques might be usefully employed.

It should also be noted that in previous work with $T$. spiralis and G. lamblia, where the $T$. spiralis infection was given prior to the $G$. lamblia, there was a strong reduction in the number of $G$. lamblia trophozoites. Our current model does not allow for the complexity of time dependency in the immune response. During the development of a model for clinical use, any time dependency in the various IAG would need to be incorporated.

Despite its quantitative shortcomings, even this simple model, based on example functional groups and derived from a very limited dataset, proves to be a useful qualitative tool in predicting the outcome of co-infection. Therefore, there should be little doubt that a more detailed model, based around functional groups, which are derived from a comprehensive dataset, could prove equally useful in a clinical setting.

\section{Objective methods for defining the IAG}

Of course, the form of grouping we have used for our example data is very subjective and ideally, especially for larger datasets, some automated, objective mechanism of grouping would be used. Although, the formulation of such a mechanism is again beyond the scope of this preliminary study, such tools do exist. One option is the use of neural networks. In particular, self-organising maps (SOM) have been successfully used to classify organisms based upon a set of traits (Park et al. 2004; Weller, Harris and Ware, 2006). These networks may be unsupervised, where no preliminary classification is known, and the SOM seeks to group data without this prior knowledge, or they may be supervised, where a classification is already known and the model then fits new data to the established criteria. The unsupervised SOM could be useful for initial immune activity group classification and the supervised SOM could then be used to fit novel organisms to this classification system.

Weller et al. (2006) successfully used unsupervised SOM to classify dinoflagellate cysts based on image data. Similarly, Park et al. (2004) used SOM in conjunction with a second method called adaptive resonance theory (ART) to successfully predict 
benthic macro-invertebrate group membership under differing water quality conditions. Further, adapted SOM can be used on categorical data (Hsu, 2006), which is the most likely form of data available for a pathogen/immunological database.

\section{Step 5: Model validations}

Once a suitable dataset has been collected, the functional groups defined and the model produced there must be a phase of validation before the model could be safely utilised in a clinical setting. At the heart of the modelling approach is the assumption that the functional groups and their predicted linkages are correct. Tests of this hypothesis could take several forms. Firstly, the limited literature describing the consequences of particular co-infections could be used as in the described example above. The pathogens in these studies could be assigned to their relevant functional groups and the predicted outcome of the model could then be checked against the experimental data in the relevant journal articles. Additionally, the model could be used to predict the outcomes of particular clinical co-infections (including the consequence of specific treatments) and these could be compared with the outcomes for those patients. Finally, where specific gaps in knowledge occur, e.g. where there is no literature or clinical data against which to test particular functional group combinations, laboratory experiments could be conducted. At each stage of model validation, the functional groups and, particularly, the linkages between the groups could be refined if errors were found.

\section{CONCLUDING REMARKS}

Once refined, the final model could be used to assess the optimal control strategies for any given network of co-infecting organisms. Perturbations of individual and multiple functional groups could be undertaken to mimic different vaccine and chemotherapeutic treatments and the effects upon all groups and upon the host (presuming a damage component is included in the model) could then be assessed.

The significance of the proposed simplification mechanism would be in offering the first step towards a generic and practical methodology for assessing control strategies in multi-pathogen infections. No such decision-support tool presently exists. While it is likely that a final model for clinical use would take several years to develop, at each step along its production path the process itself would undoubtedly increase knowledge and understanding in the rapidly growing field of co-infection biology.

\section{ACKNOWLEDGEMENTS}

The authors would like to thank the BSP co-infection symposium organising committee for their invitation to present this new idea at the symposium and for the opportunity to put this document forward for publication in Parasitology. We would also like to thank the reviewers for their helpful comments on the earlier draft of the document.

\section{REFERENCES}

Abbassi, H., Dambrine, G., Cherel, Y., Coudert, F. and Naciri, M. (2000). Interaction of Marek's disease virus and Cryptosporidium baileyi in experimentally infected chickens. Avian Diseases 44, 776-789.

Abolhassani, M. and Darabi, H. (2006). Immunosuppressive activity of Leishmania major culture supernatant. Iranian Fournal of Public Health 35, 22-27.

Abu-Raddad, L. J., Patnaik, P. and Kublin, J. G. (2006). Dual infection with HIV and malaria fuels the spread of both diseases in sub-Saharan Africa. Science 314, 1603-1606.

Allard, J. B., Poynter, M. E., Marr, K. A., Cohn, L., Rincon, M. and Whittaker, L. A. (2006). Aspergillus fumigatus generates an enhanced th2-biased immune response in mice with defective cystic fibrosis transmembrane conductance regulator. Fournal of Immunology 177, 5186-5194.

Azevedo, M. S. P., Yuan, L., Pouly, S., Gonzales, A. M., Jeong, K. I., Nguyen, T. V. and Saif, L. J. (2006). Cytokine responses in gnotobiotic pigs after infection with virulent or attenuated human rotavirus. Fournal of Virology 80, 372-382.

Baumgart, M., Tompkins, F., Leng, J. and Hesse, $M$. (2006). Naturally occurring CD4(+)Foxp3(+) regulatory $\mathrm{T}$ cells are an essential, IL-10-independent part of the immunoregulatory network in Schistosoma mansoni egg-induced inflammation. Fournal of Immunology 176, 5374-5387.

Bayraktar, M. R., Mehmet, N. and Durmaz, R. (2005). Serum cytokine changes in Turkish children infected with Giardia lamblia with and without allergy: Effect of metronidazole treatment. Acta Tropica 95, 116-122.

Becker, Y. (2006). Respiratory syncytial virus (RSV) evades the human adaptive immune system by skewing the Th1/Th2 cytokine balance toward increased levels of Th2 cytokines and IgE, markers of allergy - a review. Virus Genes 33, 235-252.

Biber, P. D., Harwell, M. A. and Cropper, W. P. (2004). Modeling the dynamics of three functional groups of macroalgae in tropical seagrass habitats. Ecological Modelling 175, 25-54.

Bilenko, N., Levy, A., Dagan, R., Deckelbaum, R. J., El-on, Y. and Fraser, D. (2004). Does co-infection with Giardia lamblia modulate the clinical characteristics of enteric infections in young children? European Fournal of Epidemiology 19, 877-883.

Blondel, J. (2003). Guilds or functional groups : does it matter? Oikos 100, 223-231.

Brown, M., Mawa, P. A., Joseph, S., Bukusuba, J., Watera, C., Whitworth, J. A. G., Dunne, D. W. and Elliott, A. M. (2005). Treatment of Schistosoma mansoni infection increases helminth-specific type 2 cytokine responses and HIV-1 loads in coinfected Ugandan adults. Fournal of Infectious Diseases 191, 1648-1657.

Cardoso, L. S., Oliveira, S. C., Pacifico, L. G. G., Goes, A. M., Oliveira, R. R., Fonseca, C. T., De Carvalho, E. M. and Araujo, M. I. (2006). Schistosoma mansoni 
antigen-driven interleukin-10 production in infected asthmatic individuals. Memorias do Instituto Oswaldo Cruz 101, 339-343.

Carlyon, J. A. and Fikrig, E. (2003). Invasion and survival strategies of Anaplasma phagocytophilum. Cellular Microbiology 5, 743-754.

Catovsky, S. (1998). Functional groups : clarifying our use of the term. Bulletin of the Ecological Society of America 79, 126-127.

Christensen, N. O., Nansen, P., Fagbemi, B. O. and Monrad, J. (1987). Heterologous antagonistic and synergistic interactions between helminths and between helminths and protozoans in concurrent experimentalinfection of mammalian hosts. Zeitschrift für Parasitenkunde-Parasitology Research 73, 387-410.

Cooper, A. M., Dalton, D. K., Stewart, T. A., Griffin, J. P., Russell, D. G. and Orme, I. M. (1993). Disseminated tuberculosis in interferon-gamma gene-disrupted mice. Fournal of Experimental Medicine 178, 2243-2247.

Coutinho, H. M., Leenstra, T., Acosta, L. P., Su, L., Jarilla, B., Jiz, M. A., Langdon, G. C., Olveda, R. M., Mcgarvey, S. T., Kurtis, J. D. and Friedman, J. F. (2006). Pro-inflammatory cytokines and C-reactive protein are associated with undernutrition in the context of Schistosoma japonicum infection. American Fournal of Tropical Medicine and Hygiene 75, 720-726.

D'orazio, S. E. F., Troese, M. J. and Starnbach, M. N. (2006). Cytosolic localization of Listeria monocytogenes triggers an early IFN-gamma response by CD8(+) $\mathrm{T}$ cells that correlates with innate resistance to infection. Fournal of Immunology 177, 7146-7154.

Davic, R. D. (2003). Linking keystone species and functional groups: A new operational defintion of the keystone species concept. Conservation Ecology 7, r11 (online).

Davis, A. J., Liu, W. C., Perner, J. and Voigt, W. (2004). Reliability characteristics of natural functional group interaction webs. Evolutionary Ecology Research 6, 1145-1166.

Dawson, H. D., Beshah, E., Nishi, S., Solano-Aguilar, G., Morimoto, M., Zhao, A. P., Madden, K. B., Ledbetter, T. K., Dubey, J. P., Shea-Donohue, T., Lunney, J. K. and Urban, J. F. (2005). Localized multigene expression patterns support an evolving Th1/ Th2-like paradigm in response to infections with Toxoplasma gondii and Ascaris suum. Infection and Immunity 73, 1116-1128.

De Bernardis, F., Lucciarini, R., Boccanera, M., Amantini, C., Arancia, S., Morrone, S., Mosca, M., Cassone, A. and Santoni, G. (2006). Phenotypic and functional characterization of vaginal dendritic cells in a rat model of Candida albicans vaginitis. Infection and Immunity 74, 4282-4294.

Deehan, M. R., Goodridge, H. S., Blair, D., Lochnit, G., Dennis, R. D., Geyer, R., Harnett, M. M. and Harnett, W. (2002). Immunomodulatory properties of Ascaris suum glycosphingolipids - phosphorylcholine and non-phosphorylcholine-dependent effects. Parasite Immunology 24, 463-469.

Deka, S., Vanover, J., Dessus-Babus, S., Whittimore, J., Howett, M. K., Wyrick, P. B. and Schoborg, R. V. (2006). Chlamydia trachomatis enters a viable but non-cultivable (persistent) state within herpes simplex virus type 2 (HSV-2) co-infected host cells. Cellular Microbiology 8, 149-162.

Dekossodo, S. and Grau, G. E. (1993). Profiles of cytokine production in relation with susceptibility to cerebral malaria. Fournal of Immunology 151, 4811-4820.

Deschoolmeester, M. L., Manku, H. and Else, K. J. (2006). The innate immune responses of colonic epithelial cells to Trichuris muris are similar in mouse strains that develop a type 1 or type 2 adaptive immune response. Infection and Immunity 74, 6280-6286.

Deshpande, P. and Shastry, P. (2004). Modulation of cytokine profiles by malaria pigment - hemozoin: role of IL-10 in suppression of proliferative repsonses of mitogen stimulated human PBMC. Cytokine 28, 205-213.

Diehl, S. and Rincon, M. (2002). The two faces of IL-6 on Th1/Th2 differentiation. Molecular Immunology 39, 531-536.

Dumay, O., Tari, P. S., Tomasini, J. A. and Mouillot, D. (2004). Functional groups of lagoon fish species in Languedoc Roussillon, southern France. Fournal of Fish Biology 64, 970-983.

Dunne, D. W., Vennervald, B. J., Booth, M., Joseph, S., Fitzsimmons, C. M., Cahen, P., Sturrock, R. F., Ouma, J. H., Mwatha, J. K., Kimani, G., Kariuki, H. C., Kazibwe, F., Tukahebwa, E. and

Kabatereine, N. B. (2006). Applied and basic research on the epidemiology, morbidity, and immunology of schistosomiasis in fishing communities on Lake Albert, Uganda. Transactions of the Royal Society of Tropical Medicine and Hygiene 100, 216-223.

Egusa, H., Nikawa, H., Makihira, S., Yatani, H. and Hamada, T. (2006). In vitro mechanisms of interleukin-8-mediated responses of human gingival epithelial cells to Candida albicans infection. International Fournal of Medical Microbiology 296, 301-311.

Farouk, S. E., Dolo, A., Bereczky, S., Kouriba, B., Maiga, B., Farnert, A., Perlmann, H., Hayano, M., Montgomery, S. M., Doumbo, O. K. and TroyeBlomberg, M. (2005). Different antibody- and cytokine-mediated responses to Plasmodium falciparum parasite in two sympatric ethnic tribes living in Mali. Microbes and Infection 7, 110-117.

Feng, C. G., Kaviratne, M., Rothfuchs, A. G., Cheever, A., Hieny, S., Young, H. A., Wynn, T. A. and Sher, A. (2006). NK cell-derived IFN-gamma differentially regulates innate resistance and neutrophil response in $\mathrm{T}$ cell-deficient hosts infected with Mycobacterium tuberculosis. Fournal of Immunology 177, 7086-7093.

Ferrari, T. C. A., Moreira, P. R. R., Sampaio, M. J., Da Cunha, A. S., De Oliveira, J. T., Gazzinelli, G. and Correa-Oliveira, R. (2006). Intrathecal cytokines in spinal cord schistosomiasis. Fournal of Neuroimmunology 177, 136-141.

Foster, T. E. and Brooks, J. R. (2005). Functional groups based on leaf physiology: are they spatially and temporally robust? Oecologia 144, 337-352.

Foulds, K. E., Rotte, M. J. and Seder, R. A. (2006). IL-10 is required for optimal CD8 T cell memory following Listeria monocytogenes infection. Fournal of Immunology 177, 2565-2574. 
Fowler, M. I., Yin, K., Humphries, H. E., Heckels, J. E. and Christodoulides, M. (2006). Comparison of the inflammatory responses of human meningeal cells following challenge with Neisseria lactamica and with Neisseria meningitidis. Infection and Immunity $\mathbf{7 4 ,}$ 6467-6478.

Fulton, E. A., Parslow, J. S., Smith, A. D. M. and Johnson, C. R. (2004). Biogeochemical marine ecosystem models II: the effect of physiological detail on model performance. Ecological Modelling 173, 371-406.

Furuta, T., Kikuchi, T., Iwakura, Y. and Watanabe, N. (2006). Protective roles of mast cells and mast cell-derived TNF in murine malaria. Fournal of Immunology 177, 3294-3302.

Furze, R. C., Hussell, T. and Selkirk, M. E. (2006). Amelioration of influenza-induced pathology in mice by coinfection with Trichinella spiralis. Infection and Immunity 74, 1924-1932.

Gbakima, A. A. (1993). The effect of dietary-protein on Trichinella spiralis infection and inflammatory reactions in the tongue in CD1 mice. Nutrition Research 13, 787-800.

Graham, A. L., Lamb, T. J., Read, A. F. and Allen, J. E. (2005). Malaria-filaria coinfection in mice makes malarial disease more severe unless filarial infection achieves patency. Fournal of Infectious Diseases 191, 410-421.

Gurish, M. F., Bryce, P. J., Tao, H., Kisselgof, A. B., Thornton, E. M., Miller, H. R., Friend, D. S. and Oettgen, H. C. (2004). IgE enhances parasite clearance and regulates mast cell responses in mice infected with Trichinella spiralis. Fournal of Immunology 172, 1139-1145.

Harms, G. and Feldmeier, H. (2002). Review: HIV infection and tropical parasitic diseases - deleterious interactions in both directions? Tropical Medicine $\mathcal{E}^{\circ}$ International Health 7, 479-488.

Helmby, H. and Grencis, R. K. (2002). IL-18 regulates intestinal mastocytosis and Th2 cytokine production independently of IFN-gamma during Trichinella spiralis infection. Fournal of Immunology 169, 2553-2560.

Hood, R. R., Laws, E. A., Armstrong, R. A., Bates, N. R., Brown, C. W., Carlson, C. A., Chai, F., Doney, S. C., Falkowski, P. G., Feely, R. A., Friedrichs, M. A. M., Landry, M. R., Moore, J. K., Nelson, D. M., Richardson, T. L., Salihoglu, B., Schartau, M., Toole, D. A. and Wiggert, J. D. (2006). Pelagic functional group modeling: Progress, challenges and prospects. Deep-Sea Research Part II-Topical Studies in Oceanography 53, 459-512.

Hsu, C. C. (2006). Generalizing self-organizing map for categorical data. Ieee Transactions on Neural Networks 17, 294-304.

Hughes, C. A. and Shafran, S. D. (2006). Treatment of hepatitis C in HIV-coinfected patients. Annals of Pharmacotherapy 40, 479-489.

Jiang, B., Snipes-Magaldi, L., Dennehy, P., Keyserling, H., Holman, R. C., Bresee, J., Gentsch, J. and Glass, R. I. (2003). Cytokines as mediators for or effectors against rotavirus disease in children. Clinical and Diagnostic Laboratory Immunology 10, 995-1001.

John, C. C., Opika-Opoka, R., Byarugaba, J., Idro, R. and Boivin, M. J. (2006). Low levels of RANTES are associated with mortality in children with cerebral malaria. Fournal of Infectious Diseases 194, 837-845.

Karosi, T., Jokay, I., Konya, J., Szabo, L. Z., Pytel, J., Jori, J., Szalmas, A. and Sziklai, I. (2006). Detection of osteoprotegerin and TNF-alpha mRNA in ankylotic staples footplates in connection with measles virus positivity. Laryngoscope 116, 1427-1433.

Khan, W. I., Vallance, B. A., Blennerhasset, P. A., Deng, Y., Verdu, E. F., Matthaei, K. I. and Collins, S. M. (2001). Critical role for signal transducer and activator of transcription factor 6 in mediating intestinal muscle hypercontractility and worm expulsion in Trichinella spiralis-infected mice. Infection and Immunity 69, 838-844.

King, J. R., Andersen, A. N. and Cutter, A. D. (1998). Ants as bioindicators of habitat disturbance: validation of the functional group model for Australia's humid tropics. Biodiversity and Conservation 7, 1627-1638.

Kontorinis, N., Agarwal, K. and Dieterich, D. T. (2005). Treatment of hepatitis $\mathrm{C}$ virus in HIV patients: a review. Aids 19, S166-S173.

Kosonen, J., Rantala, A., Little, C. H., Lintu, P., Harjamaki, P. R., Georgiou, G. M., Cone, R. E. and Savolainen, J. (2006). Increased levels of Candida albicans mannan-specific $\mathrm{T}$-cell-derived antigen binding molecules in patients with invasive candidiasis. Clinical and Vaccine Immunology 13, 467-474.

Kringel, H., Iburg, T., Dawson, H., Aasted, B. and Roepstorff, A. (2006). A time course study of immunological responses in Trichuris suis infected pigs demonstrates induction of a local type 2 response associated with worm burden. International Fournal for Parasitology 36, 915-924.

Lello, J., Boag, B., Fenton, A., Stevenson, I. R. and Hudson, P. J. (2004). Competition and mutualism among the gut helminths of a mammalian host. Nature 428, 840-844.

Li, E. Q., Zhou, P. and Singer, S. M. (2006). Neuronal nitric oxide synthase is necessary for elimination of Giardia lamblia infections in mice. Fournal of Immunology 176, 516-521.

Liew, F. Y., Xu, D. M., Brint, E. K. and O'neill, L. A. J. (2005). Negative regulation of Toll-like receptor-mediated immune responses. Nature Reviews Immunology 5, 446-458.

Liu, Q., Liu, Z. G., Alem, F., Whitmire, J., Urban, J. and Gause, W. (2005). IL-18 induces IL-4 independent IL-13 mediated host resistance to Trichuris muris. FASEB Fournal 19, A938-A938.

Loeuillet, C., Martinon, F., Perez, C., Munoz, M., Thome, M. and Meylan, P. R. (2006). Mycobacterium tuberculosis subverts innate immunity to evade specific effectors. Fournal of Immunology 177, 6245-6255.

McConchie, B. W., Norris, H. H., Bundoc, V. G., Trivedi, S., Boesen, A., Urban, J. F. and KeaneMyers, A. M. (2006). Ascaris suum-derived products suppress mucosal allergic inflammation in an interleukin-10-independent manner via interference with dendritic cell function. Infection and Immunity 74, 6632-6641.

Mikhailova, A. A., Belevskaya, R. G., Kalyuzhnaya, M., Fonina, L. A., Liashenko, V. A. and Petrov, R. V. (2006). Myelopeptide-2 recovers interleukin-2 synthesis and interleukin-2 receptor expression in human 
$\mathrm{T}$ lymphocytes depressed by tumor products or measles virus. Fournal of Immunotherapy 29, 306-312.

Milcu, A., Partsch, S., Langel, R. and Scheu, S. (2006). The response of decomposers (earthworms, springtails and microorganisms) to variations in species and functional group diversity of plants. Oikos 112, 513-524.

Morales, P., Reyes, P., Vargas, M., Rios, M., Imarai, M., Cardenas, H., Croxatto, H., Orihuela, P., Vargas, R., Fuhrer, J., Heckels, J. E., Christodoulides, M. and Velasquez, L. (2006). Infection of human Fallopian tube epithelial cells with Neisseria gonorrhoeae protects cells from tumor necrosis factor alpha-induced apoptosis. Infection and Immunity 74, 3643-3650.

Mukherjee, P., Sen, P. C. and Ghose, A. C. (2006). Lymph node cells from BALB/c mice with chronic visceral leishmaniasis exhibiting cellular anergy and apoptosis: Involvement of Ser/Thr phosphatase. Apoptosis 11, 2013-2029.

Mullen, A. B., Lawrence, C. E., Mcfarlane, E., Wei, X. Q. and Carter, K. C. (2006). Endogenous interleukin-18 is involved in immunity to Leishmania donovani but its absence does not adversely influence the therapeutic activity of sodium stibogluconate. Immunology 119, 348-354.

Onah, D. N. and Wakelin, D. (1999). Trypanosomeinduced suppression of responses to Trichinella spiralis in vaccinated mice. International Fournal for Parasitology 29, 1017-1026.

Ozoren, N., Masumoto, J., Franchi, L., Kanneganti, T. D., Body-Malapel, M., Erturk, I., Jagirdar, R., Zhu, L., Inohara, N., Bertin, J., Coyle, A., Grant, E. P. and Nunez, G. (2006). Distinct roles of TLR2 and the adaptor ASC in IL-1 beta/IL-18 secretion in response to Listeria monocytogenes. Fournal of Immunology 176, 4337-4342.

Page, K. R., Scott, A. L. and Manabe, Y. C. (2006). The expanding realm of heterologous immunity: friend or foe? Cellular Microbiology 8, 185-196.

Parekh, S. B., Bubb, W. A., Hunt, N. H. and Rae, C. (2006). Brain metabolic markers reflect susceptibility status in cytokine gene knockout mice with murine cerebral malaria. International Fournal for Parasitology 36, 1409-1418.

Park, Y. S., Chon, T. S., Kwak, I. S. and Lek, S. (2004). Hierarchical community classification and assessment of aquatic ecosystems using artificial neural networks. Science of the Total Environment 327, 105-122.

Parthasarathy, G. and Mansfield, L. S. (2005). Trichuris suis excretory secretory products (ESP) elicit interleukin-6 (IL-6) and IL-10 secretion from intestinal epithelial cells (IPEC-1). Veterinary Parasitology 131, 317-324.

Paterson, J. C. M., Garside, P., Kennedy, M. W. and Lawrence, C. E. (2002). Modulation of a heterologous immune response by the products of Ascaris suum. Infection and Immunity 70, 6058-6067.

Pedersen, A. B. and Fenton, A. (2007). Emphasizing the ecology in parasite community ecology. Trends in Ecology \&ீ Evolution 22, 133-139.

Pepe, M., Altamura, M., Spinelli, R., Calvello, R., Saccia, M., Cavallo, P., Covelli, V., Jirillo, E. and Brandonisio, O. (2006). Toll-like receptor-positive cells and recognition of pathogens: How human myeloid dendritic cells respond to in vitro infection with Leishmania infantum. Current Pharmaceutical Design 12, 4255-4262.

Perona-Wright, G., Jenkins, S. J. and Macdonald, A. S. (2006). Dendritic cell activation and function in response to Schistosoma mansoni. International Fournal for Parasitology 36, 711-721.

Petchey, O. L. and Gaston, K. J. (2006). Functional diversity: back to basics and looking forward. Ecology Letters 9, 741-758.

Poorter, L., Bongers, L. and Bongers, F. (2006). Architecture of 54 moist-forest tree species: Traits, trade-offs, and functional groups. Ecology 87, 1289-1301.

Popov, A., Abdullah, Z., Wickenhauser, C., Saric, T., Driesen, J., Hanisch, F. G., Domann, E., Raven, E. L., Dehus, O., Hermann, C., Eggle, D., Debey, S., Chakraborty, T., Kronke, M., Utermohlen, O. and Schultze, J. L. (2006). Indoleamine 2,3-dioxygenaseexpressing dendritic cells form suppurative granulomas following Listeria monocytogenes infection. Fournal of Clinical Investigation 116, 3160-3170.

Ramharter, M., Kremsner, P. G., Willheim, M., Winkler, H., Graninger, W. and Winkler, S. (2004). Plasmodium falciparum-specific interleukin-2 and tumor necrosis factor-alpha expressing-T cells are associated with resistance to reinfection and severe malaria in healthy African children. European Cytokine Network 15, 189-196.

Reimert, C. A., Fitzsimmons, C. M., Joseph, S., Mwatha, J. K., Jones, F. M., Kimani, G., Hoffmann, K. F., Booth, M., Kabatereine, N. B., Dunne, D. W. and Vennervald, B. J. (2006). Eosinophil activity in Schistosoma mansoni infections in vivo and in vitro in relation to plasma cytokine profile pre- and posttreatment with praziquantel. Clinical and Vaccine Immunology 13, 584-593.

Riffault, S., Dubuquoy, C., Castagne, N., Baranowski, E., Charley, B. and Eleouet, J. F. (2006). Replication of Bovine respiratory syncytial virus in murine cells depends on type I interferon-receptor functionality. Fournal of General Virology 87, 2145-2148.

Roberts, M. T. M. (2005). Current understandings on the immunology of leishmaniasis and recent developments in prevention and treatment. British Medical Bulletin 75-76, 115-130.

Roberts-Thomson, I. C., Grove, D. I., Stevens, D. P. and Warren, K. S. (1976). Suppression of giardiasis during intestinal phase of trichinosis in mouse. Gut 17, 953-958.

Rockstroh, J. K. (2006). Management of hepatitis C/HIV coinfection. Current Opinion in Infectious Diseases 19, 8-13.

Rousseau, D., Lefichoux, Y., Stien, X., Suffia, I., Ferrua, B. and Kubar, J. (1997). Progression of visceral leishmaniasis due to Leishmania infantum in BALB/c mice is markedly slowed by prior infection with Trichinella spiralis. Infection and Immunity $\mathbf{6 5}$, 4978-4983.

Santiago, H. C., Pires, M. F. B., Souza, D. G., Roffe, E., Cortes, D. F., Tafuri, W. L., Teixeira, M. M. and Vieira, L. Q. (2006). Platelet activating factor receptor-deficient mice present delayed interferon-gamma upregulation and high susceptibility 
to Leishmania amazonensis infection. Microbes and Infection 8, 2569-2577.

Seixas, E. and Ostler, D. (2005). Plasmodium chabaudi chabaudi (AS): Differential cellular responses to infection in resistant and susceptible mice. Experimental Parasitology 110, 394-405.

Seoh, J. Y., Khan, M., Park, S. H., Park, H. K., Shin, M. H., Ha, E. H., Lee, B. E., Yoo, K., Han, H. S., Oh, S., Wi, J. H., Hong, C. K., Oh, C. H., Kim, Y. A. and Park, J. W. (2003). Serum cytokine profiles in patients with Plasmodium vivax malaria: A comparison between those who presented with and without hyperpyrexia. American Fournal of Tropical Medicine and Hygiene $\mathbf{6 8}$, 102-106.

Sharma, S. K., Farah, D., Misra-Bhattacharya, S., Bajpai, P., Agarwal, A. and Mohammad, O. (2006). Escheriosome entrapped soluble blood stage antigens impart protective immunity against a multi-drug resistant isolate of Plasmodium yoelii nigeriensis in BALB/c mice. Vaccine 24, 948-956.

Shumilla, J. A., Lacaille, V., Hornell, T. M. C., Huang, J., Narasimhan, S., Relman, D. A. and Mellins, E. D. (2004). Bordetella pertussis infection of primary human monocytes alters HLA-DR expression. Infection and Immunity 72, 1450-1462.

Singer, S. M. and Nash, T. E. (2000). T-cell-dependent control of acute Giardia lamblia infections in mice. Infection and Immunity 68, 170-175.

Sousa-Pereira, S. R., Teixeira, A. L., Silva, L. C. S., Souza, A. L. S., Antunes, C. M., Teixeira, M. M. and Lambertucci, J. R. (2006). Serum and cerebral spinal fluid levels of chemokines and Th2 cytokines in Schistosoma mansoni myeloradiculopathy. Parasite Immunology 28, 473-478.

Souza, V. M. O., Jacysyn, J. F. and Macedo, M. S. (2004). IL-4 and IL-10 are essential for immunosuppression induced by high molecular weight proteins from Ascaris suum. Cytokine 28, 92-100.

Stadecker, M. J., Asahi, H., Finger, E., Hernandez, H. J., Rutitzky, L. I. and Sun, J. (2004). The immunobiology of Th1 polarization in high-pathology schistosomiasis. Immunological Reviews 201, 168-179.

Stebbing, J., Waters, L., Mandalia, S., Bower, M., Nelson, M. and Gazzard, B. (2005). Hepatitis C virus infection in HIV type 1 -infected individuals does not accelerate a decrease in the CD4 $(+)$ cell count but does increase the likelihood of AIDS-defining events. Clinical Infectious Diseases 41, 906-911.

Stevens, D. A. (2006). Th1/Th2 in aspergillosis. Medical Mycology 44, S229-S235.

Stewart, M. J., Kulkarni, S. B., Meusel, T. R. and Imani, F. (2006). c-Jun N-terminal kinase negatively regulates dsRNA and RSV induction of tumor necrosis factor-alpha transcription in human epithelial cells. Fournal of Interferon and Cytokine Research 26, 521-533.

Storkey, J. (2006). A functional group approach to the management of $\mathrm{UK}$ arable weeds to support biological diversity. Weed Research 46, 513-522.

Sullivan, P. S., Hanson, D. L., Teshale, E. H., Wotring, L. L. and Brooks, J. T. (2006). Effect of hepatitis $\mathrm{C}$ infection on progression of HIV disease and early response to initial antiretroviral therapy. Aids 20, 1171-1179.
Taylor, M. D., Betts, C. J. and Else, K. J. (2000). Peripheral cytokine responses to Trichuris muris reflect those occurring locally at the site of infection. Infection and Immunity 68, 1815-1819.

Thom, M. L., Hope, J. C., Mcaulay, M., VillarrealRamos, B., Coffey, T. J., Stephens, S., Vordermeier, H. M. and Howard, C. J. (2006). The effect of tuberculin testing on the development of cell-mediated immune responses during mycobacterium bovis infection. Veterinary Immunology and Immunopathology 114, 25-36.

Tishon, A., Lewicki, H., Andaya, A., Mcgavern, D., Martin, L. and Oldstone, M. B. A. (2006). CD4 T cell control primary measles virus infection of the CNS : Regulation is dependent on combined activity with either CD8 T cells or with B cells: CD4, CD8 or B cells alone are ineffective. Virology 347, 234-245.

Torres, D., Janot, L., Quesniaux, V. F. J., Grivennikov, S. I., Maillet, I., Sedgwick, J. D., Ryffel, B. and Erard, F. (2005). Membrane tumor necrosis factor confers partial protection to Listeria infection. American Fournal of Pathology 167, 1677-1687.

Turner, J. D., Faulkner, H., Kamgno, J., Cormont, F., Van Snick, J., Else, K. J., Grencis, R. K., Behnke, J. M., Boussinesq, M. and Bradley, J. E. (2003). Th2 cytokines are associated with reduced worm burdens in a human intestinal helminth infection. Fournal of Infectious Diseases 188, 1768-1775.

Vallance, B. A., Matthaei, K. I., Sanovic, S., Young, I. G. and Collins, S. M. (2000). Interleukin-5 deficient mice exhibit impaired host defence against challenge Trichinella spiralis infections. Parasite Immunology 22, 487-492.

Vancott, J. L., Prada, A. E., Mcneal, M. M., Stone, S. C., Basu, M., Huffer, B., Smiley, K. L., Shao, M. Y., Bean, J. A., Clements, J. D., Choi, A. H. C. and Ward, R. L. (2006). Mice develop effective but delayed protective immune responses when immunized as neonates either intranasally with nonliving VP6/LT(R192G) or orally with live rhesus rotavirus vaccine candidates. Fournal of Virology $\mathbf{8 0}$, 4949-4961.

von Allmen, N., Christen, S., Forster, U., Gottstein, B., Welle, M. and Muller, N. (2006). Acute trichinellosis increases susceptibility to Giardia lamblia infection in the mouse model. Parasitology 133, 139-149.

Walz1, G., Tafuro, S., Moss, P., Openshaw, P. J. M. and Hussell, T. (2000). Influenza virus lung infection protects from respiratory syncytial virus-induced immunopathology. Fournal of Experimental Medicine 192, 1317-1326.

Wang, H. W., Peters, N. and Schwarze, J. (2006). Plasmacytoid dendritic cells limit viral replication, pulmonary inflammation, and airway hyperresponsiveness in respiratory syncytial virus infection. Fournal of Immunology 177, 6263-6270.

Wardle, D. A. and Zackrisson, O. (2005). Effects of species and functional group loss on island ecosystem properties. Nature 435, 806-810.

Warrender, C., Forrest, S. and Koster, F. (2006). Modeling intercellular interactions in early 
Mycobacterium infection. Bulletin of Mathematical Biology 68, 2233-2261.

Weller, A. F., Harris, A. J. and Ware, J. A. (2006). Artificial neural networks as potential classification tools for dinoflagellate cyst images: A case using the self-organizing map clustering algorithm. Review of Palaeobotany and Palynology 141, 287-302.

Werling, D., Howard, C. J., Niederer, E., Straub, O. C., Saalmuller, A. and Langhans, W. (1998). Analysis of the phenotype and phagocytic activity of monocytes/macrophages from cattle infected with the bovine leukaemia virus. Veterinary Immunology and Immunopathology 62, 185-195.

Wieland, C. W., Florquin, S., Pater, J. M., Weijer, S. and Van Der Poll, T. (2006). Interleukin-1 contributes to an effective clearance of Mycobacterium kansasii from the respiratory tract. Microbes and Infection $\mathbf{8}$, 2409-2413.

Xu, J., Yang, Y., Sun, J., Ding, Y., Su, L., Shao, C. and Jiang, B. (2006). Expression of Toll-like receptors and their association with cytokine responses in peripheral blood mononuclear cells of children with acute rotavirus diarrhoea. Clinical and Experimental Immunology 144, 376-381.

Yanagi, Y., Takeda, M. and Ohno, S. (2006). Measles virus: cellular receptors, tropism and pathogenesis. Fournal of General Virology 87, 2767-2779.

Zarantonelli, M. L., Huerre, M., Taha, M. K. and Alonso, J. M. (2006). Differential role of lipooligosaccharide of Neisseria meningitidis in virulence and inflammatory response during respiratory infection in mice. Infection and Immunity 74, 5506-5512. 